\title{
The rise and rise of dining out in New Zealand
}

\section{Marisa Bidois}

Marisa Bidois was appointed to her role as CEO of the Restaurant Association of New Zealand in 2011 and has now led the association for nearly seven years. Before becoming CEO, Bidois was professional development manager for the association's Auckland function facility, Taste, and looked after its employment relations and legal queries for four years. She has also worked outside of the industry, but always makes her way back because of the people from all walks of life who gather in the hospitality industry.

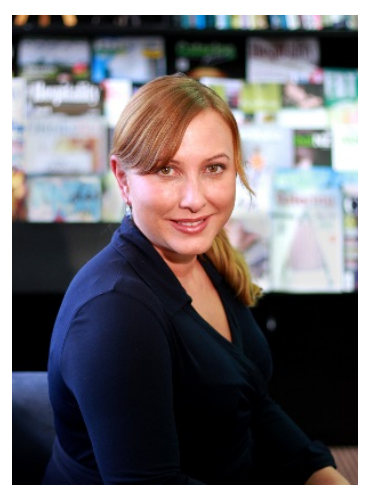

The 2018 Restaurant Association Hospitality Report [1] shows Kiwis are eating out more often, for a wider range of occasions. The latest report finds that nationwide sales for the hospitality industry have continued to grow, with takeaway food recording the highest growth.

In 2018, New Zealand's hospitality sector achieved record sales of over $\$ 11.2$ billion (year end, March). This represents sales growth of 3.6 percent over the previous year, which after two years of significant growth (8.2 percent from 2016-2017 and 9.7 percent from 2015-2016) settles at a more stabilised level in 2018. Conversely, EFTPOS data shows that grocery sales are continuing to slow, pointing to people eating out more often, replacing meals that may traditionally have been eaten at home. Over the past five years, there has been a slowdown in year-on-year supermarket sales growth from 4.9 percent in 2014 to 3.9 percent this year [2].

A recent My Food Bag and Stuff survey showed that only 52 percent of parents now eat at home every night. Statistics NZ data [3] shows that more than a quarter (26 percent) of all food spending is now at restaurants and on ready-toeat meals, such as takeaway hot drinks and takeaway pizzas (compared with 23 percent in 2014). The takeaway/food-to-go sector is recording the highest growth. Sales for the food-to-go sector grew 5.7 percent in 2018. In dollar terms, this translates to an increase in annual sales of \$148 million. But it seems we Kiwis are still hooked on dining out, with restaurants and cafés the biggest winners and accounting for $\$ 5.6$ billion of all hospitality sales.

Consumer spending is highest in Auckland, Wellington and Christchurch. These three regions all have annual sales of more than $\$ 1$ billion per annum. The Ministry of Business Innovation and Employment (MBIE) forecast an annual employment growth for the hospitality sector of 2.7 percent per annum through to 2026. For the period 2016-2017, however, the industry achieved employment growth of almost three times that, at 6.8 percent. The total number of people employed in hospitality is now just under 130,000, with more than 72,000 in restaurants and cafés.

Hospitality business owners rank their number one challenge as the lack of skilled employees, followed by managing wage costs. This competition for skilled employees has the potential to drive wage rises in some regions, although operators also look for creative ways to retain employees to ensure their labour costs are kept under control. Wages have the potential to rise beyond customers' 
expectation of price rises, and that's a challenge and a balancing act that hospitality business owners must face. The challenge for hospitality owners to find staff is compounded by the number of new businesses opening every week, although to a certain extent this is offset by a comparable number of businesses closing. In 2017, while more than 2,700 new businesses opened, due to those closures, the volume of new outlets overall was an increase of 534 new establishments.

The hospitality industry has performed exceptionally well in recent years and, although 2018 sees more restrained growth, the industry is well positioned to face the challenges of its competitive operating environment. Although a more cautious outlook is expected for the remainder of 2018, there are also opportunities for operators - particularly for those that deliver an exceptional offering to customers and for those that embrace both changing consumer dining trends and developments in technology to help grow their businesses.

Highlights:

- Nationwide sales for the hospitality industry in 2018 (year end, March) increased by 3.6 percent, to exceed $\$ 11$ billion.

- The sales growth in 2018 carried across all sectors, excluding the clubs sector, with takeaway/food-to-go recording the highest growth of 5.7 percent.

- Regionally, revenue growth in the Bay of Plenty region was highest for the second year in a row at 6.8 percent, followed by Auckland at 5.1 percent.

- In 2017, the number of hospitality businesses nationwide increased by 534 to 17,328 .

- The industry currently employs almost 130,000 people.

- The top challenges identified by the industry are a lack of skilled employees, wage costs, and building and maintaining sales.

\section{Corresponding author}

Marisa Bidois can be contacted at: marisa@restaurantnz.co.nz

\section{References}

(1) Restaurant Association. Annual Hospitality Report 2018,

2018. https://www.restaurantnz.co.nz/product/2018-hospitality-report/

(2) Marketview. Consumer Spending Year Ending June

2018. https://marketview.co.nz/news/ (accessed Aug 18, 2018).

(3) Stats NZ. Retail Trade Survey: March 2018

Quarter. https://www.stats.govt.nz/information-releases/retail-trade-survey-march-2018quarter (accessed Sep 5, 2018). 